\title{
Ischemic Preconditioning and/or Propofol Ameliorate Hepatic Injury in Experimental Rats
}

\author{
MOHAMED EL-SAYED MAHMOUD, M.D.* and MOHAMED Sh. NEGM, M.D.** \\ The Departments of Medical Pharmacology* and Pathology**, Faculty of Medicine, Cairo University, Egypt
}

\begin{abstract}
Background: Ischaemic Preconditioning is an efficient maneuver to ameliorate liver injury by induction of endogenous defence against ischemia. Propofol is widely used in general anesthesia, and it has been reported to protect various organs against ischemia-reperfusion injury (IRI), including liver.
\end{abstract}

Aim of Study: To study hepatoprotective effects of ischemic preconditioning (IP) and/or propofol, and the possible underlying mechanisms in rats.

Material and Methods: 30 Male Spraguee Dawley rats were divided into 5 groups: Sham group (n 6), non-IP group (n 6; 45 minutes of hepatic ischemia followed by 2 hours of reperfusion), and IP group (n 6; IP applied as 10 minutes of hepatic ischemia followed by 15 minutes of reperfusion before 45 minutes of ischemia, propofol group (n 6) infused $800 \mu \mathrm{g} /$ $\mathrm{kg} / \mathrm{min} 45$ minutes of hepatic ischemia followed by 2 hours of reperfusion, propofol and IP group n 6. Anesthesia was maintained with intraperitoneal xylazine. Liver enzymes, histopathological changes, and cytokine expression were assessed.

Results: The Ischaemic Preconditioning, propofol and Ischaemic Preconditioning-propofol groups showed significantly lower liver enzyme levels and reduced the histologic scoring of liver 2 hours after reperfusion compared to the non-IP group. Lactate dehydrogenase activity and interleukin6 mRNA levels were significantly higher in the non-IP group than in the sham and IP groups.

Conclusions: Our results demonstrate that IP and propofol significantly attenuated hepatic IRI. The principal mechanism of the protective effects through reduced expression of the IL-6 pro-inflammatory cytokine and propofol antiapoptic effect with subsequent reduction of the degree of necrosis.

Key Words: Ischaemic preconditioning - Propofol-Ischaemia reperfusion injury - Liver.

\section{Introduction}

PRINGLE maneuver is commonly done during hepatic surgery in which liver blood supply are

Correspondence to: Dr. Mohamed El-Sayed Mahmoud,

The Department of Medical Pharmacology,

Faculty of Medicine, Cairo University, Egypt clamped. Total hepatic ischemia/reperfusion is commonly found in the central macrosection of the liver tumor or the liver area. Recent studies reported that hepatic ischemia-reperfusion injury (HIRI, I/RI) has local and general reaction which influence function of liver and damage for far organs [1-4]. The main mechanisms may be derived from increased oxygen radical and calcium overload in cells, and the former is the most important factor [5-7]. In our study we try to prevent and cure post-HIRI liver injury.

IRI is an important cause of morbidity and mortality in patients during liver surgery, and intermittent interruption of hepatic blood flow. Mechanisms of hepatic IRI include microcirculation dysfunction, reactive oxygen species (ROS), activation of Kupffer cells, and calcium overload, which cause liver dysfunction [3]. The main mechanisms may be increased oxygen radical and calcium over-load in cells, and the former is the most important factor [5].

Murry et al., [4] are the first that demonstrated the protective effects of ischemic preconditioning (IP) against myocardial IRI [4,5] .

IP is an efficient maneuver to ameliorate liver injury by induction of endogenous defence against ischemia.

Propofol (2, 6-diisopropylphenol) is an intravenous (IV) anesthetic agent used to induce and maintain anesthesia. It has been demonstrated that IP with the commonly used volatile agents, isoflurane, and sevoflurane show protective effects against hepatic IRI in rats [6,7]. Propofol also ameliorate liver damage. Propofol has been widely applied in current clinical anesthesia, and it is the common drug to study protection of ischemia reperfusion injury. Propofol can protect far organs in liver ischemia reperfusion in rats [15]. 


\section{Material and Methods}

\section{Chemicals and reagents:}

Propofol Sandoz milky white liquid in a clear vial available as sterile emulsion USA); Propofol Sandoz Emulsion for injection (S4) Propofol; glycerol, soya oil, egg lecithin; white; aqueous Xylazine (Solution, Adwia; Egypt); AST, ALT, $\mathrm{LDH}$, Serum tumor necrosis factor-alpha (TNFa), interleukin-1 beta (IL- 1beta) and interleukin6 (IL-6) concentrations ELIZA kits (SigmaAldrich).

\section{Animals:}

30 Male Spraguee Dawley rats (weight, 280 to $320 \mathrm{~g}$; age, 7 to 8 weeks), purchased from animal house; Research Institute of Ophthalmology; Giza, Egypt. All experimental procedures will be performed according to The Recommendations from the Instituional animal care and use committee (IACUC) Cairo University. Before the commencement of any intervention, this study was approved by (IACUC). This study was carried out in the Pharmacology Department, Faculty of Medicine, Cairo University, 2021.

\section{Experimental prorocol:}

Male Sprague Dawley rats (weight, 280 to $320 \mathrm{~g}$; age, 7 to 8 weeks), maintained under standard laboratory conditions at $25^{\circ} \mathrm{C} \&$ normal photoperiod (12 hr dark/12 hr light) are used for the experiment.

\section{Experimental design:}

Male Spraguee Dawley rats (weight, 280 to $320 \mathrm{~g}$; age, 7 to 8 weeks) were used:

Thirty rats were randomly divided into the following 5 groups:

- Group I: Control group (sham, n 6).

- Group II: Hepatic ischemia-reperfusion (IR) group (non-IP, n 6).

- Group III: IP group (n 6).

- Group IV: Propofol group (n 6).

- Group V: IP and Propofol goup (n. 6).

\section{Interventions:}

Surgery was performed by the same researcher under aseptic conditions. The rats were anesthetized with xylazine $100 \mathrm{mg} / \mathrm{kg}$ intraperitoneal. All rats were set on an electrical heating pad in a supine position, A $5 \mathrm{~mL}$ saline solution were injected hourly into the intraperitoneum for hydration. Tracheal intubation was performed with cannula, and the lungs were ventilated mechanically at 50 to 65 breaths/min (Bioscience, United Kingdom).
The femoral artery was cannulated to monitor mean arterial blood pressure (MAP) and obtain blood samples. After stabilizations, a 4cm midline laparotomy were performed with local anesthesia using $1 \%$ lidocaine. When the abdominal cavity was exposed, the falciform ligament were resected. Depending on the assigned group, a microvascular clamp was applied at the portal triad to the median and left lateral liver lobes. The microvascular clamp was maintained during 45 minutes of ischemia in the non-IP group, and the rats were observed in the laparotomy state for 2 hours after reperfusion.

In the IP group, 10 minutes of IP were induced followed by $15 \mathrm{~min}$ of reperfusion before 45 minutes of hepatic ischemia [8,9]. The duration of IP and sustained ischemia as previous studies [6,7]. In propofol group is infused at rat of $800 \mathrm{~g} / \mathrm{k} / \mathrm{min}$.

After this period, the surgical procedures were the same as those in the non-IP group. At 2 hours of reperfusion, all the rats were sacrificed.

\section{Biochemical measurements:}

Serum levels of AST aminotransferase (AST, a nonspecific marker for hepatic injury) \& ALT aminotransferase (ALT, a specific marker for hepatic parenchymal injury were measured initially (before hepatic ischemia, AST1, and ALT1) and 2 hours after reperfusion (AST2 and ALT2). Using ELIZA kits assay (Sigma-Aldrich; USA).

Serum Lactate Dehydrogenase (LDH) was measuered using ELISA KITS (Sigma-Aldrich, St. Louis, Mo, United States).

Serum tumor necrosis factor-alpha (TNF-a), interleukin-1 beta (IL-1beta), interleukin-6 (IL-6) and $\mathrm{Bcl}-2$ concentrations were measured with ELISA kits that specifically designed for rat cytokines, and all measurements were performed in accordance with the manufacturer's instructions

Tumour necrosis factor $\alpha(\mathrm{TNF} \alpha)$ and interleukin-1 $\beta$ (IL-1 $\beta$ ) are pleiotropic mediators of biologic responses related to infection, immunity, and inflammation (Le and Vilcek, 1987). IL-1, TNF $\alpha$ and IL- 6 are cytokines with overlapping biological properties which form a complex network of interactive signals. They are considered major mediators of fever and the production of acute phase proteins (Baumann and Gauldie, 1990).

\section{Tissue collection:}

After the operation, liver samples were obtained from the anterior edge of the median lobe at the time of sacrifice. 


\section{Histopathological:}

Presentative sections were sampled from dissected organs in cassettes and were fixed in formaline $10 \%$ for 24 hour then processed in tissue processor overnight. Paraffin blocks were prepared. One section was cut from each paraffin block by microtome at 5 microns thickness; then stained with hematoxylin and Eosin for routine histopathoogical examination.

Haematoxylin and Eosin ( $H \&$ E): (1) Deparaffinise in xylene-2 changes. (2) Absolute alcohol. (3) $95 \%$ alcohol. (4) Rinse in tap water. (5) Harris haematoxylin-6 minutes. (6) Wash in tap water. (7) Decolorize with $1 \%$ acid-alcohol-quick dips. 8. Wash in tap water. (9) Blue in $1 \%$ lithium carbonate - 2-3 dips. (10) If lithium carbonate is not available, use ammonia water. (11) Wash with tap water (check under the microscope-nuclei should be distinct blue and the background light or colorless). (12) If it is not well stained, stain again in
Harris" haematoxylin for 2-3 minutes. (13) If over stained decolorize again with $1 \%$ acid alcohol quick dips. (14) Wash with tap water. (15) Counter stain in 1\% eosin-2-3 quick dips. (16) Wash quickly with tap water. (17) 95\%, alcohol. (18) Absolute alcohol-2 changes. (19) Xylene - 2 changes. (20) Mount.

\section{Results: Nuclei-Blue Cytoplasm-Pale pink.}

Photography: The digital images of the selected tissue preparations were photographed using a Olympus DP26 digital net camera attached to a Olympus CX31 Microscope.

Concerning the liver biopsies, grading of inflammation according to ISHAK scoring system, these assign numbers to the severity of the necroinflammatory features (interface hepatitis, confluent necrosis, parenchymal injury and portal inflammation) and add the numbers to arrive at a grade that can range from 0 to 18 .

ISHAK score.

\begin{tabular}{|c|c|c|c|c|c|c|c|}
\hline $\begin{array}{l}\text { Periportal or periseptal } \\
\text { interface hepatitis } \\
\text { (piecemeal necrosis) }\end{array}$ & & Confluent necrosis & & $\begin{array}{l}\text { Focal (spotty) lytic } \\
\text { necrosis, } \\
\text { apoptosis and } \\
\text { focal inflammation }\end{array}$ & & $\begin{array}{c}\text { Portal } \\
\text { inflammation }\end{array}$ & \\
\hline None & 0 & None & 0 & None & 0 & None & \\
\hline Mild (focal, few portal areas) & 1 & Focal confluent necrosis & 1 & $\begin{array}{l}\text { One focus or less } \\
\text { per } 10 \bullet \text { objective }\end{array}$ & 1 & $\begin{array}{l}\text { Mild some or } \\
\text { all portal tracts }\end{array}$ & 1 \\
\hline $\begin{array}{l}\text { Mild/moderate } \\
\text { (focal, most portal areas) }\end{array}$ & 2 & Zone 3 necrosis in some areas & 2 & $\begin{array}{l}\text { Two to four foci } \\
\text { per } 10 \bullet \text { objective }\end{array}$ & 2 & $\begin{array}{l}\text { Moderate some or } \\
\text { all portal tracts }\end{array}$ & \\
\hline $\begin{array}{l}\text { Moderate (continuous around } \\
<50 \% \text { of tracts or septa) }\end{array}$ & 3 & Zone 3 necrosis in most areas & 3 & $\begin{array}{l}\text { Five to ten foci } \\
\text { per } 10 \bullet \text { objective }\end{array}$ & 3 & $\begin{array}{l}\text { Moderate/marked in } \\
\text { all portal tracts }\end{array}$ & 3 \\
\hline \multirow[t]{3}{*}{$\begin{array}{l}\text { Severe (continuous around } \\
>50 \% \text { of tracts or septa) }\end{array}$} & 4 & $\begin{array}{l}\text { Zone } 3 \text { necrosis + occasional } \\
\text { portal-central bridging }\end{array}$ & 4 & $\begin{array}{l}\text { More than } 10 \text { foci } \\
\text { per } 10 \bullet \text { objective }\end{array}$ & 4 & $\begin{array}{r}\text { Marked in all } \\
\text { portal tracts }\end{array}$ & \\
\hline & & $\begin{array}{l}\text { Zone } 3 \text { necrosis + multiple } \\
\text { portal-central bridging }\end{array}$ & 5 & & & & \\
\hline & & Panacinar or multiacinar necrosis & 6 & & & & \\
\hline
\end{tabular}

\section{Statistical analysis:}

Data was transferred to the Statistical Package of Social Science Software program, version 24 (SPSS) to be statistically analyzed.

Data was summarized using mean, and standard deviation for quantitative variables and frequency and percentage for qualitative ones.

Comparison between groups was performed using one way ANOVA with Tukey's post hoc test for quantitative variables and Chi square or Fissure exact test for qualitative ones.

$p$-values less than 0.05 were considered statistically significant, and less than 0.01 were considered highly significant.

\section{Results}

\section{Group I: Control group (sham, $N$ 6):}

Mean arterial blood pressure: (MAP): Within normal range allthrough the experiment.

\section{AST and ALT:}

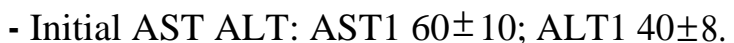

- Two hours after reperfusion: AST2: $55 \pm 9$; ALT2: $60 \pm 8$. Table (1).

- LDH activity two hours after reperfusion: 640 $\pm 280 \mathrm{mU} / \mathrm{mL}$ Table 2).

- Il-1 $\beta$, IL-6 TNF- $\alpha$ and Bcl-2 at 2 hours after reperfusion: Within normal range (Table 3 ). 
Histopathologically: The portal tracts are within normal. The hepatocytes are within normal. ISHAK 0 (H\&E, 100x) Fig. (1).

Group II: Hepatic ischemia-reperfusion (IR) group (non-IP, $N$ 6):

Mean arterial blood pressure: (MAP): Within normal range allthrough the experiment.

\section{AST and ALT:}

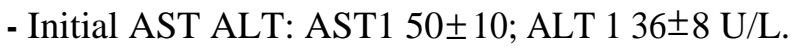

- Two hours after reperfusion: AST2: $600 \pm 86$; ALT2: $580 \pm 18 \mathrm{U} / \mathrm{L}$. Which is signifantly higher than group I ( $p$-value <0.05) Table (1).

- LDH activity two hours after reperfusion: $2300 \pm 227 \mathrm{mU} / \mathrm{mL}$. Which is signifantly higher than group I ( $p$-value <0.05) Table (2).

- IL 1- $\beta$, IL-6; TNF- $\alpha$ and Bcl-2, at 2 hours after reperfusion: A significant high level. W is signifantly higher than group I Table (3).

Histopathologically: Sections revealed liver tissue showing two foci of spotty necrosis. ISHAK 8 (H\&E, 200x): Sections examined revealed liver tissue of rat. The hepatocytes showed minimal hydropic degeneration. The portal tract showed mild inflammatory cellular infiltrate including lymphocytes and plasma cells. Focal interface hepatitis seen. Fig. (2).

\section{Group III: IP Group (N 6):}

Mean arterial blood pressure: (MAP): Within normal range allthrough the experiment.

\section{AST and ALT:}

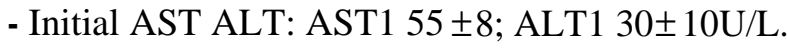

- Two hours after reperfusion: AST2: $300 \pm 50$; ALT2: $220 \pm 40 U / L$. Show significant lower level vs. non IP group Table (1).

- LDH activity two hours after reperfusion: $1450 \pm 222 \mathrm{mU} / \mathrm{mL}$. Show significant lower level vs. non IP group Table (2).

- Il-1 $\beta$; IL-6 TNF- $\alpha$ and Bcl-2 at 2 hours after reperfusion: Show lower level than non IP group however IL6 significantly lower vs. non-IP group Table (3).

Histopathologically: Sections revealed liver tissue. The portal tracts are expanded by mixed inflammatory cellular infiltrate with focal interface hepatitis. The hepatocytes showed focus of spotty necrosis. ISHAK 4 (H\&E, 100x) Fig. (3).

\section{Group IV: Propofol group (N 6):}

Mean arterial blood pressure: (MAP): Within normal range allthrough the experiment).
AST and ALT:

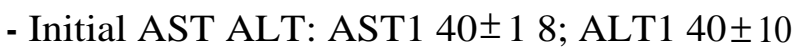
$\mathrm{U} / \mathrm{L}$.

- Two hours after reperfusion: AST2: $240 \pm 48$; ALT2: $200 \pm 40 U / L$ show significant lower level vs. non IP Table (1).

- LDH activity two hours after reperfusion: $1360 \pm 130 \mathrm{mU} / \mathrm{mL}$. Show significant lower level vs. non IP Table (2).

- TNF- $\alpha$, and IL- $1 \beta$ at 2 hours after reperfusion: Within higher levels however IL6 and Bcl-2 significantly lower vs. non-IP group Table (3).

Histopathologically: Sections examined revealed liver tissue. A focus of spotty necrosis seen. ISHAK 3 (H\&E, 200x) Fig. (4).

\section{Group V: IP and propofol (N 6):}

Mean arterial blood pressure: (MAP): Within normal range allthrough the experiment.

\section{AST and ALT:}

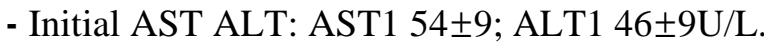

- Two hours after reperfusion: AST2: $180 \pm 40$; ALT2: $160 \pm 30$ U/L. Show significant lower level vs. non IP F. (1).

- LDH activity two hours after reperfusion: $1160 \pm 140 \mathrm{mU} / \mathrm{mL}$. Show significant lower level vs. non IP Fig. (2).

- TNF- $\alpha$, and IL-1 $\beta$ at 2 hours after reperfusion: Within normal range however IL6 and Bcl-2 significantly lower vs. non-IP group Table (3).

Histopathologically: Sections revealed liver tissue. The portal tracts are within normal. The hepatocytes are within normal. ISHAK 1 (H\&E, 100x) Fig. (5).

Table (1): Serum levels of aspartate aminotransferase (AST) and alanine aminotransferase (ALT).

\begin{tabular}{llllll}
\hline & Group I & Group II & Group III & Group IV & Group V \\
\hline AST1 & $60 \pm 10$ & $50 \pm 10$ & $55 \pm 8$ & $40 \pm 18$ & $54 \pm 9$ \\
ALT 1 & $40 \pm 8$ & $36 \pm 8$ & $30 \pm 10$ & $40 \pm 8$ & $46 \pm 9$ \\
AST2 & $55 \pm 9 \#$ & $600 \pm 86 * \#$ & $300 \pm 50^{*}$ & $240 \pm 48 *$ & $180 \pm 40^{*}$ \\
ALT2 & $60 \pm 8 \#$ & $580 \pm 18 * \#$ & $220 \pm 40^{*}$ & $200 \pm 40 *$ & $160 \pm 30^{*}$ \\
\hline
\end{tabular}

A- AST1: ALT1 levels before hepatic ischemia. B- AST2 : ALT2 level at 2 hours after reperfusion. ALT $2: * p$-value $<0.05$ group II vs other groups. $\# p$-value is 0.001 group II vs group I. AST2 : * $p$-value $<0.05$ group II vs other groups. $\# p$-value is 0.001 group II vs group I. 
Table (2): Lactate dehydrogenase (LDH) activity assay 2 hours after reperfusion. IP, ischemic preconditioning; Non-IP, non-ischemic preconditioning.

\begin{tabular}{rcccc}
\hline Group I & Group II & Group III & Group IV & Group V \\
\hline LDH 640 & $2300 \pm 227$ & $1450 \pm$ & $1360 \pm$ & $1160 \pm$ \\
$280^{*}$ & $* \#, \# \#, \# \# \#$ 222\# & $130 \# \#$ & $140 \# \#$ \\
\hline
\end{tabular}

*Group II vs group I, $p .001$.

\#Group II vs group III\#.

IV\#\#

V\#\#\#, $p$-value $(<.005 ; 0.05 ; 0.001)$ respectively.

Table (3): Serum levels of interleukin $1 \beta$ ( IL-1 $\beta$ ), interleukin6 (IL-6), tumor necrosis factor- $\alpha$ (TNF- $\alpha$ ) and Bcl2.

\begin{tabular}{lllll}
\hline & IL $1 \beta$ & \multicolumn{1}{c}{ IL 6} & TNF $\alpha$ & Bcl-2 \\
\hline Group I & $26 \pm 4$ abc & $25 \pm 10 \#$ & $75 \pm 20$ & $30 \pm 10$ \\
Group II & $120 \pm 10 \mathbf{a}$ & $130 \pm 14 \#$ & $150 \pm 14$ & $120 \pm 30^{*}$ \\
Group III & $110 \pm 12 \mathbf{b}$ & $83 \pm 9$ & $140 \pm 24$ & $100 \pm 24$ \\
Group IV & $100 \pm 14 \mathbf{c}$ & $80 \pm 16$ & $126 \pm 16$ & $40 \pm 10$ \\
Group V & $80 \pm 20 \mathbf{d}$ & $54 \pm 11$ & $104 \pm 12$ & $28 \pm 8^{*}$ \\
\hline
\end{tabular}

a Denotes significant difference between Group I vs Group II $p$-value 0.001

b Denotes significant difference between Group I vs Group III $p$-value $<0.01$

c Denotes significant difference between Group I vs Group IV $p$-value 0.01

d Denotes significant difference between Group I vs Group V $p$-value $<0.05$

\# Denotes significant difference between Group I vs Group II $p$-value 0.001

* Denotes significant difference between Group II vs Group V $p$-value 0.001 .

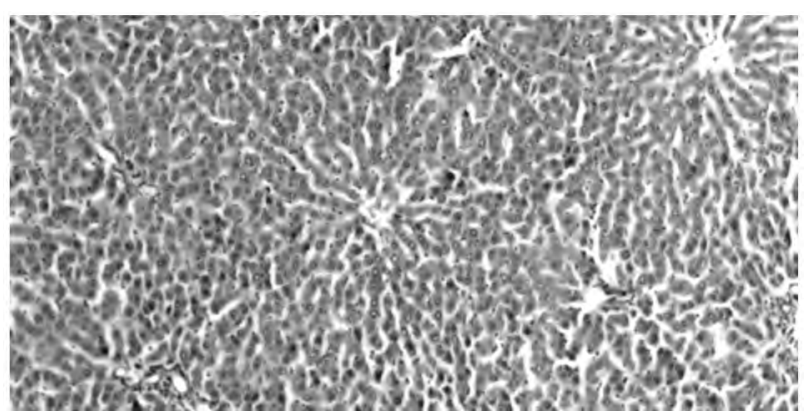

Fig. (1): Sections revealed liver tissue. The portal tracts are within normal. (H\&E, 200x) Ishak sore 0.

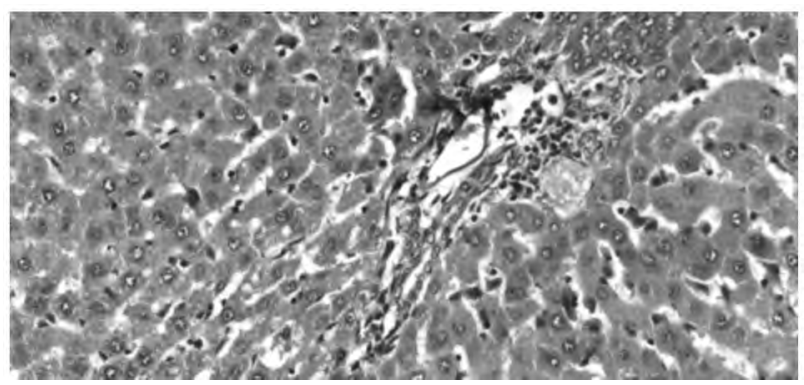

Fig. (2): Sections revealed liver tissue. The portal tracts are expanded by mixed inflammatory cellular infiltrate with focal interface hepatitis. The hepatocytes showed focus of spotty necrosis. ISHAK 8 (H\&E, 200x).

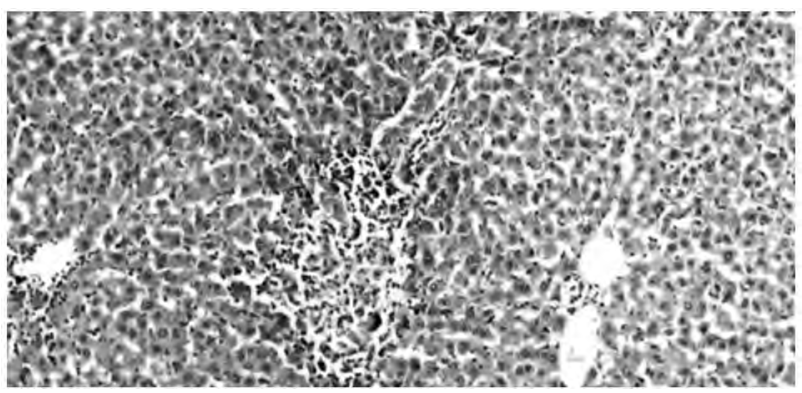

Fig. (3): Sections revealed liver tissue. The portal tracts are expanded by mixed inflammatory cellular infiltrate with focal interface hepatitis. The hepatocytes showed focus of spotty necrosis. ISHAK 4 (H\&E, 100x).

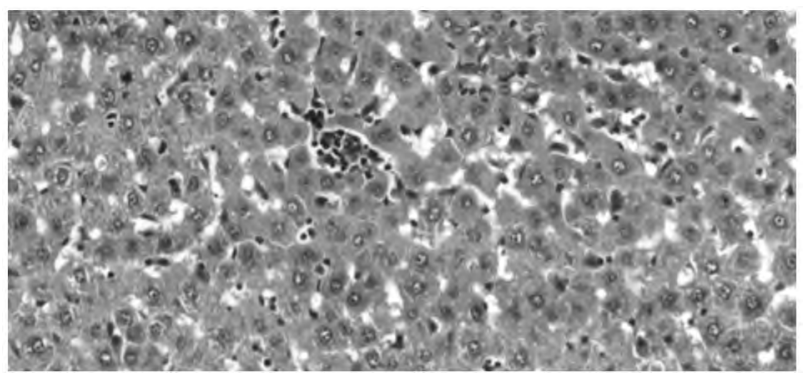

Fig. (4): Sections examined revealed liver tissue. A focus of spotty necrosis seen. ISHAK 3 (H\&E, 200x).

\section{Discussion}

Our study showed that IP and/or propofol attenuated hepatic IRI in rats where serum transaminases levels and histologic findings results shoed. IP and propofol provide protection to the liver and far organs, by increasing tolerance against organ hypoxia $[11,12]$

Propofol and its lipid vehicles are metabolized mainly in the liver and eliminated by the liver and kidneys [13]. Yamada et al., [14] assessed the interaction between aneshetic conditioning (sevoflurane vs propofol) and IP on metabolic function after hepatic IRI in rabbits. They showed that galactose clearance, a surrogate marker for hepatocyte function, was increased in propofol group with IP, and it represented that application of IP may be selectively protective and propofol.

In contrast, the results of our study revealed that IP effectively attenuated hepatic IRI as shown by the lower level of LDH activity. LDH activity is a necrosis indicator and it was used as a direct marker of cell damage induced by hepatic IRI. Moreover, improved serum transaminase levels and less severe morphologic changes in hepatocytes were observed 2 hours after reperfusion by applying IP and propofol or both.

IL-6 plays a major role in host defense and inflammation, and it is produced by immune cells 
at the injury site as a consequence of systemic insults [15]. Previous experimental study reported that IP reduces the expression of IL- 6 accompanied by alleviated hepatic IRI in rats undergoing liver transplantation [16]. They suggested that IP alleviated hepatic IRI associated with suppressing IL6 expression. In agreement to these results, the expression of IL-6, the pro-inflammatory cytokine, was significantly reduced after IP and propofol in our study. Thus, we suggest that the principle protective mechanism of IP under propofol anesthesia might be associated with reduction of inflammation and subsequent reduction of the degree of necrosis.

$\mathrm{Bcl}-2$ is an indicator of apoptosis and decreased by administration of propofol which indicate an anti-opoptic effect.

A previous study compared liver enzymes and histopathological results at different times after reperfusion [17]. The authors concluded that prolonged ischemia $>2$ hours increases hepatocellular necrosis without increasing apoptosis. Longer periods of time after reperfusion might permit the detection of various changes in cytokine expression, leading to different outcomes.

In conclusion, the results of this study showed that IP and/or propofol significantly attenuated hepatic IRI as demonstrated by improved liver function tests, the principal mechanism underlying the protective effects of IP appeared to involve downregulation of LDH activity, IL-6 expression and $\mathrm{Bcl}-2$ level.

\section{References}

1- NAGINO M., KAMIYA J., ARAI T., NISHIO H., EBATA T. and NIMURA Y.: One hundred consecutive hepatobiliary resections for biliary hilar malignancy: Preoperative blood donation, blood loss, transfusion, and outcome. Surgery, 137: 148e55, 2005.

2- JAESCHKE H.: Mechanisms of reperfusion injury after warm ischemia of the liver. J. Hepatobiliary Pancreat Surg., 5: 402e8, 1998.

3- CHOUKER A., SCHACHTNER T., SCHAUER R., et al.: Effects of Pringle manoeuvre and ischaemic preconditioning on haemodynamic stability in patients undergoing elective hepatectomy: A randomized trial. Br. J. Anaesth., 93: 204e11, 2004.

4- MURRY C.E., JENNINGS R.B. and REIMER K.A.: Preconditioning with ischemia: A delay of lethal cell injury in ischemic myocardium. Circulation, 74: 1124e36, 1986.
5- PETROWSKY H., McCORMACK L., TRUJILLO M., SELZNER M., JOCHUM W. and CLAVIEN P.A.: A prospective, randomized, controlled trial comparing intermittent portal triad clamping versus ischemic preconditioning with continuous clamping for major liver resection. Ann. Surg., 244: 921e8. discussion 8-30, 2006.

6- KO J.S., GWAK M.S., KIM G.S., et al.: The protective effect of ischemic preconditioning against hepatic ischemic-reperfusion injury under isoflurane anesthesia in rats. Transplant Proc., 45: 1704e7, 2013.

7- JEONG J.S., KIM D., KIM K.Y., et al.: Ischemic preconditioning produces comparable protection against hepatic ischemia/reperfu-sion injury under isoflurane and sevoflurane anesthesia in rats. Transplant Proc., 49: 2188e93, 2017.

8- CLAVIEN P.A., YADAV S., SINDRAM D. and BENTLEY R.C.: Protective effects of ischemic preconditioning for liver resection performed under inflow occlusion in humans. Ann. Surg., 232: 155e62, 2000.

9- YADAV S.S., SINDRAM D., PERRY D.K., CLAVIEN P.A.: Ischemic preconditioning protects the mouse liver by inhibition of apoptosis through a caspase-dependent pathway. Hepatology, 30: 1223e31, 1999.

10- BEDIRLI N., OFLUOGLU E., KEREM M., et al.: Hepatic energy metabolism and the differential protective effects of sevoflurane and isoflurane anesthesia in a rat hepatic ischemia-reperfusion injury model. Anesth. Analg., 106: 830e7, 2008.

11- VASDEKIS S.N., ATHANASIADIS D., LAZARIS A., et al.: The role of remote ischemic preconditioning in the treatment of atherosclerotic diseases. Brain Behav., 3: 606e 16,2013

12- LAZARIS A.M., MAHERAS A.N. and VASDEKIS S.N.: Remote ischemic preconditioning: Myth or reality? J. Endovasc. Ther., 16: 694e5, 2009.

13- TAKIZAWA D., HIRAOKA H., GOTO F., YAMAMOTO K. and HORIUCHI R.: Human kidneys play an important role in the elimination of pro-pofol. Anesthesiology, 102: $327 \mathrm{e} 30,2005$.

14- YAMADA T., NAGATA H., KOSUGI S., SUZUKI T., MORISAKI $H$. and KOTAKE Y.: Interaction between anesthetic conditioning and ischemic preconditioning on metabolic function after hepatic ischemia-reperfusion in rabbits. J. Anesth., 32: 599e607, 2018.

15- NORRIS C.A., HE M., KANG L.I., et al.: Synthesis of IL- 6 by he-patocytes is a normal response to common hepatic stimuli. PLoS One, 9: e96053, 2014.

16- CUI L.Z., WANG B., CHEN L.Y. and ZHOU J.: The effect of ischemic precondition to IL-6 on rat liver ischemia-reperfusion injury in transplantation. Asian Pac. J. Trop. Med., 6: 395e9, 2013.

17- GUJRAL J.S., BUCCI T.J., FARHOOD A. and JAESCHKE H.: Mechanism of cell death during warm hepatic ischemia-reperfusion in rats: Apoptosis or necrosis? Hepatology, 33: 397e405, 2001. 


\section{التهيئة المسبقة I للكبد و / أو دواء البروبوفول

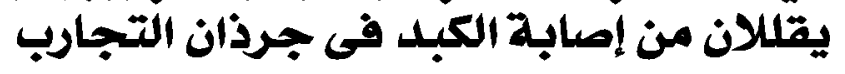

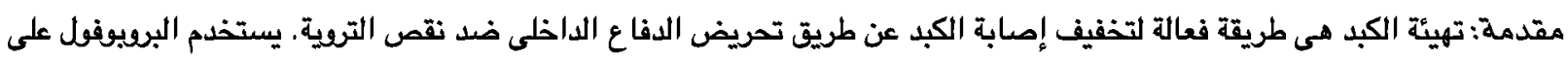
نطاق واسع فى التخدير العام، وقد تم ذكر عنه حماية الأعضاء المختلفة من إصابة نقص التروية فعرية (IRI)، بما في ذلك الكبد . الهدف من الدراسة: دراسة التائيرات الوقائية الكبدية التكييف المسبق الإقفارى و / أو البروبوفل، والآليات الكامنة المحتملة فى الجراذن. فى هذه الدراسة تم تقسيم • r من ذكود جرذان إلى ه مجموعات كل مجموعة ستة جرذان مجموعة الأولى (ن T)، مجموعة غير تهيئة الجرذان

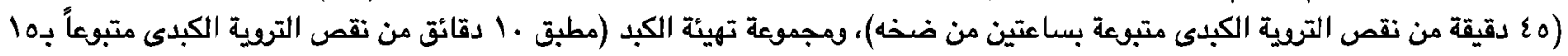

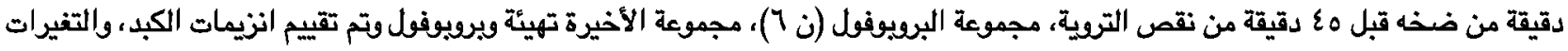

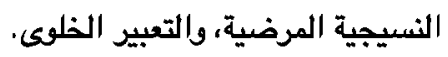

نتأج: أظهرت مجموعات الثالثة والرابعة والخامسة انخفاضاً ملحظاً فى مستويات إنزيم الكبد وتقليل التسجيل النسيجى مقارنة بالمجموعة غير تهيئة الكبد كان نشاط نازعة هيلروجين اللاكتات و مستويات انترلوكين-7 مرناً أعلى بشكل ملحوظ في المجموعة التى لا تنتمى إلى تهيئة

الاستتاجات: تظهر نتائجنا أن تهيئة الكبد والبربوفول خففا بشكل كبير من إصابة الكبد من خلال تقليل التعبير عن السيتوكين المؤيد

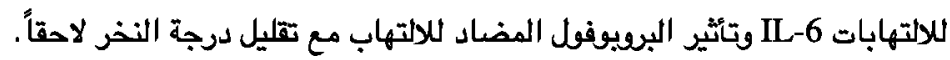

